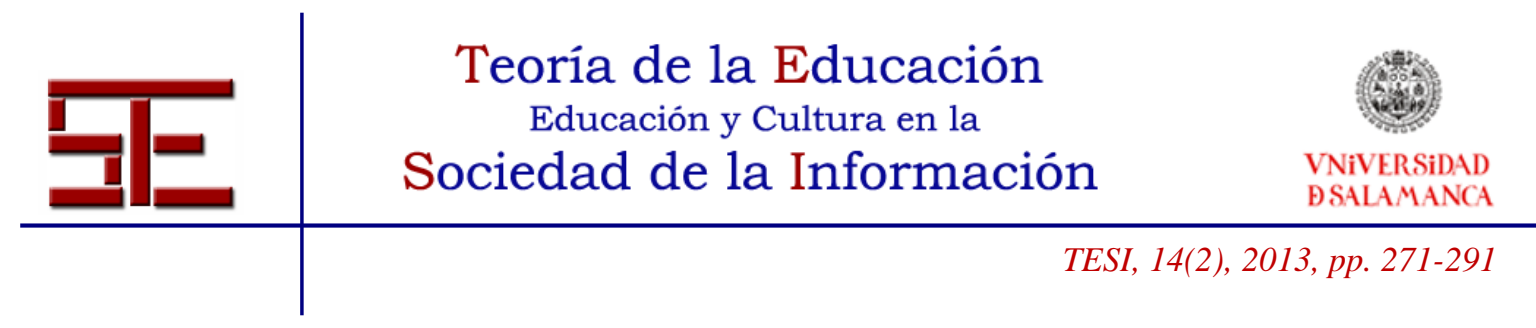

\title{
CÓMO DEFINIR PROYECTOS DE M-LEARNING MÁS SOSTENIBLES
}

Resumen: Los teléfonos móviles son usados ampliamente tanto en países ricos como en países pobres, a diferencia de lo que ocurre con otras TIC. La expansión de la telefonía móvil en los países pobres presenta una oportunidad para luchar contra la fractura digital. En estos últimos países, los teléfonos móviles se utilizan para conseguir información y servicios sobre agricultura, sanidad, educación entre otros ámbitos. Concretamente, en el área de la educación son muchos los que piensan que los teléfonos móviles serán una herramienta muy útil para ayudar a conseguir la educación primaria universal, uno de los Objetivos del Milenio propuestos por las Naciones Unidas. Existen, muchas experiencias con teléfonos móviles que dan soporte a la educación (estas experiencias forman parte de lo que se conoce en la literatura como mobile-learning o m-learning). Pero la mayoría de estas experiencias tienen serias limitaciones que afectan a su sostenibilidad a largo plazo. En esta línea, el presente trabajo pretende aportar una serie de guías para definir proyectos de m-learning más sostenibles y viables a largo plazo.

Palabras clave: m-learning; sostenibilidad; dispositivos móviles; desarrollo.

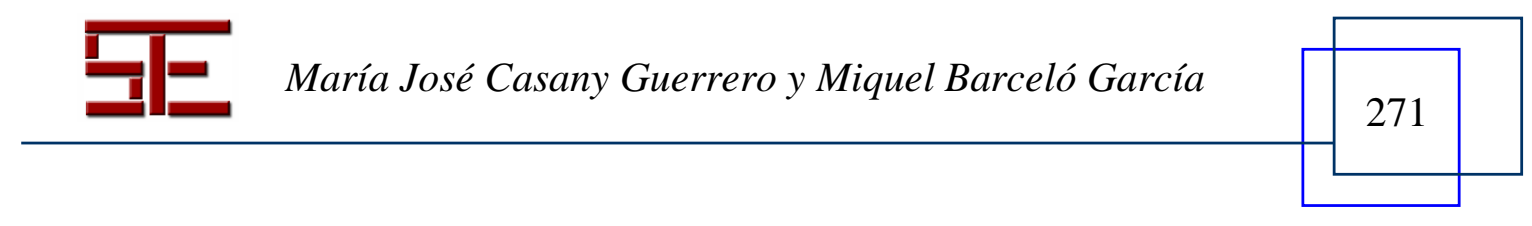




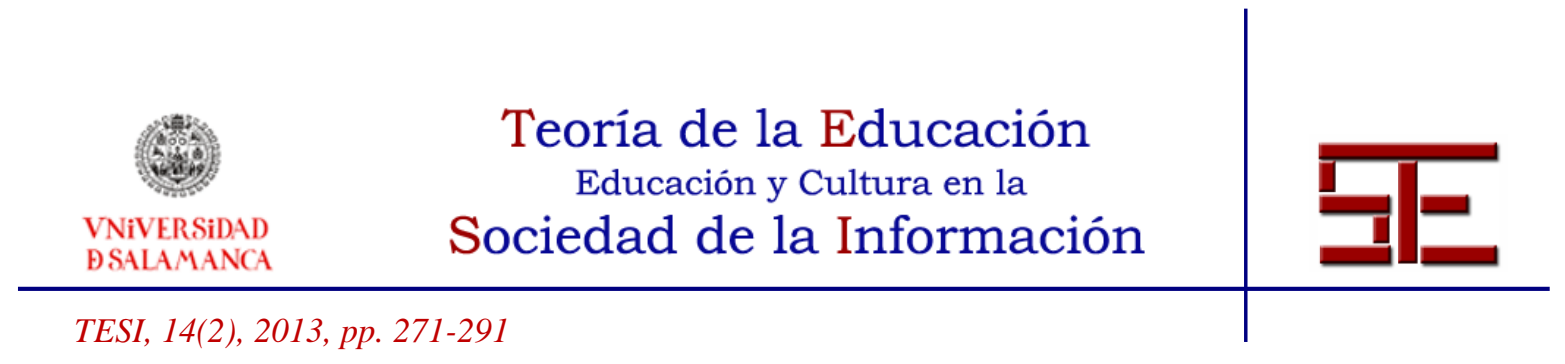

HOW TO DEFINE MORE SUSTAINABLE M-LEARNING PROJECTS

\begin{abstract}
Mobile phones are widely used in both rich and poor countries, unlike what happens with other ICTs. The expansion of mobile telephony in poor countries presents an opportunity to fight against the digital divide. In the latter countries, mobile phones are used to get information and services about agriculture, health, and education among other areas. Specifically in the area of education there are many who think that mobile phones are a useful tool to help achieve universal primary education, one of the Millennium Development Goals proposed by the United Nations. There are many educational experiences with mobile phones (these experiences are part of what is known in literature as a mobile-learning or m-learning). But most of these experiences have serious limitations that affect their long-term sustainability. In this line, the current paper provides a set of guidelines to define more sustainable and long-term viable m-learning projects.
\end{abstract}

Keywords: m-learning; sustainability; mobile phones; development; FOSS.

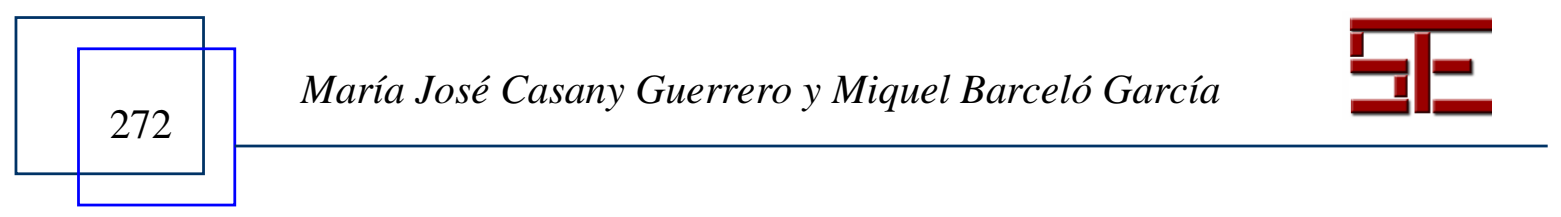




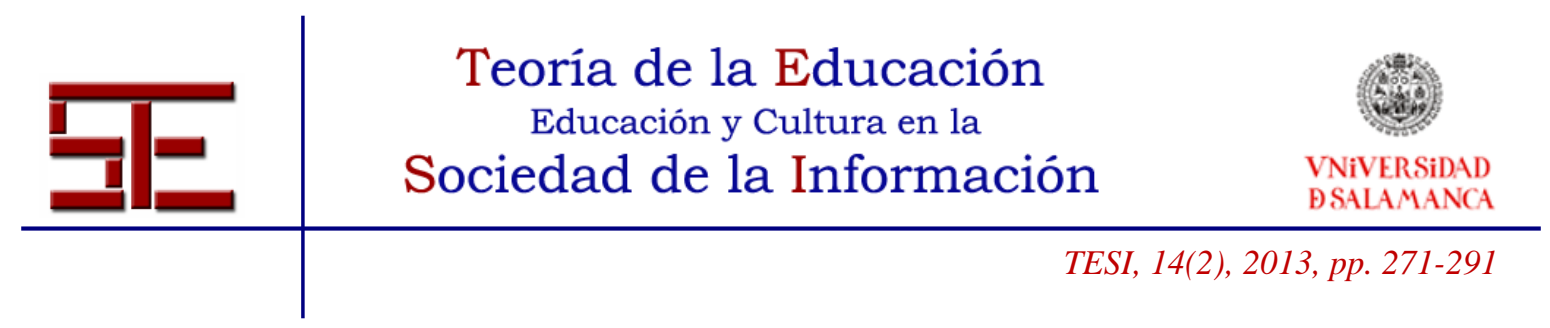

\section{HOW TO DEFINE MORE SUSTAINABLE M-LEARNING PROJECTS FOR DEVELOPMENT}

Fecha de recepción: 07/12/2012; fecha de aceptación: 27/03/2013; fecha de publicación: 30/07/2013

María José Casany Guerrero

mjcasany@essi.upc.edu

Universitat Politècnica de Catalunya

Miquel Barceló García

blo@essi.upc.edu

Universitat Politècnica de Catalunya

\section{1.- INTRODUCTION}

Information and Communication Technology (ICT) is regarded as a powerful tool for development. Nevertheless, most ICTs face many problems in developing countries, in part due to the lack of adequate infrastructures. But despite those problems, there is one technology that is widely used and expanding in developing countries: mobile phones. In the Information Society Report 2010 published by the International Telecommunication Union (ITU), the developing countries are experiencing an important increase on the use of mobile phones. The ITU states that: "In developing world mobile cellular penetration is $68 \%$ at the end od 2010 , driven specially by Asia and Pacific region. In Africa region, penetration rates reach $41 \%$ leaving a significant potential for growth" (ITU, 2010, 2).

The proliferation of mobile phones in developing countries is due to several factors summarized below. One of the most important ones is the relatively low cost of the mobile terminal. In many of the world countries, it is possible to find a mobile phone for a relatively low cost. This is due to the existence of a second hand market that allows people from developing countries to buy a mobile phone for a low price. These second hand market starts in the developed countries, where people tend to change their mobile phone regularly. These terminals that are no longer used in the developed countries, are sold in the developing countries for a lower price (Banks, 2008).

Moreover, mobile phones are personal devices that serve many purposes for its owner: communications, photo and video camera or music. In developing countries they also have other uses, such as lanterns, since public illumination coverage is very low and many

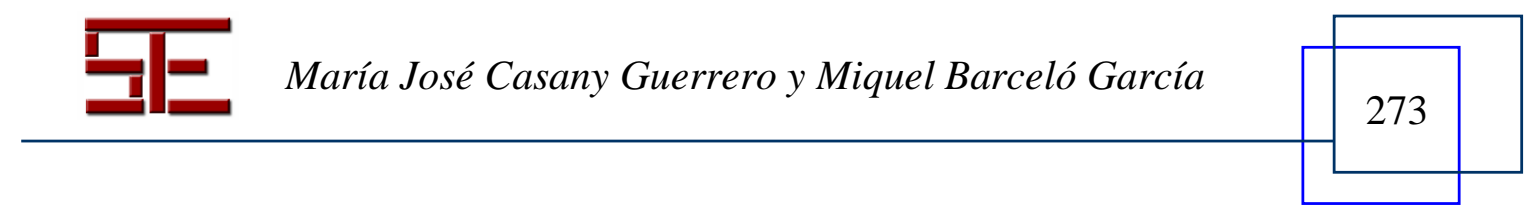




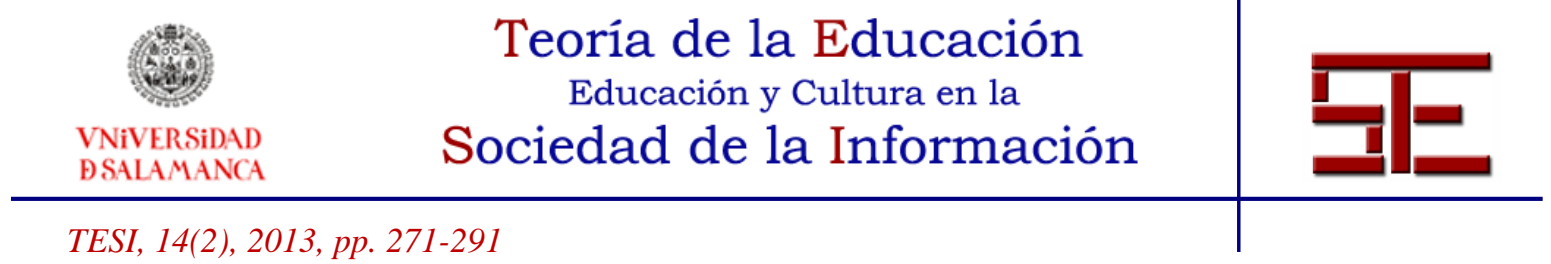

homes do not have electric power supply. For many people in developing countries, mobile phones are their only computing device and they have become portable networked computers (Banks, 2008; Peña-López, 2008).

In developing countries, there is high demand of information related to health, agriculture and education. SMS-based applications have covered this gap in the last years, creating a huge market for SMS. So SMS-based applications and in general, mobile technologies are providing information services to a large percentage of the population. When mobile technologies offer open and general-purpose systems, the people have figured out ways to use the technologies to satisfy their needs. People in developing countries are innovators since they have created unique ways to use ICT. For example, "sente" is an informal way to send money to someone using a local Kiosk operator (Peña-López, 2008). Since many times, mobile phones are the only computing device for local people and there is also a high demand of information related to education, mobile applications can be very useful to support educational processes. The use of mobile devices for learning is called m-learning (Sharples, 2006). There are currently many m-learning projects in developing countries. But most of them are pilots or small-scale projects based on external funding that lack the ability to be maintained, updated and extended. This paper presents a series of guidelines to implement more sustainable m-learning projects.

This work is organized as follows: section two analyses the main opportunities and challenges of mobile devices in developing countries. Section three presents the related work regarding m-learning in devolving countries. Section four presents the main guidelines to implement more sustainable m-learning projects and section five presents the conclusions of this work.

\section{2.- MOBILE DEVICES: OPPORTUNITIES AND CHALLENGES}

2.1.- Factors that have influenced the expansion of mobile technology in developing countries

One of the factors that have promoted the penetration of mobile telephony in the poorest African countries was the privatization of telephone monopolies in these countries during the 1990s. Since the privatization of state monopolies, private operators that emerged speeded up the introduction of new technology particularly mobile phones. These private companies started to sell mobile phones and calls to an increasingly lower price (Shanmugavelan; Warnock; De Sarkar, 2009). This price reduction was one of the factors

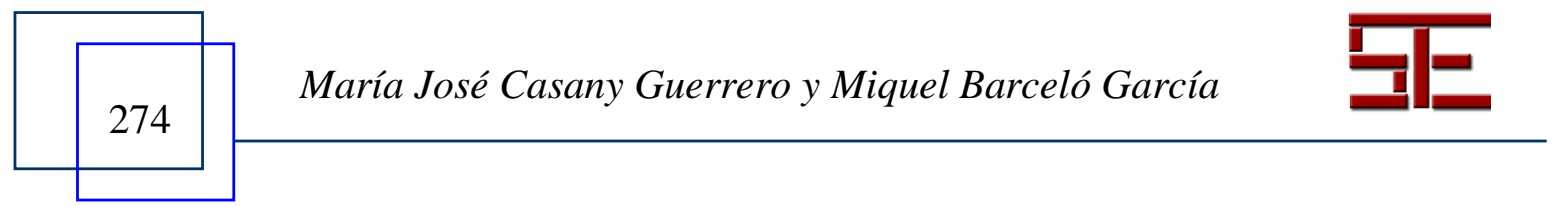




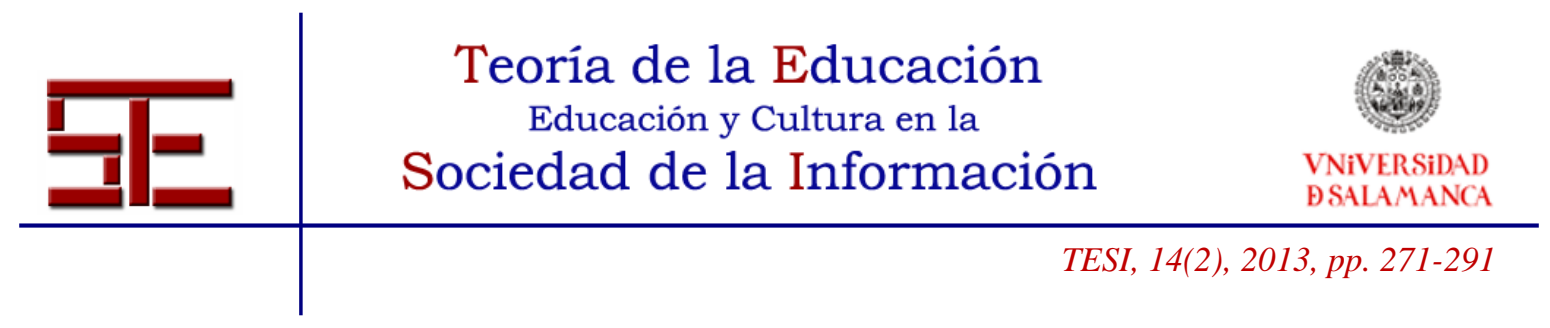

that led to the expansion of mobile phones in Africa, to the point that now mobile phones represent a technological revolution in Africa, equivalent to television revolution in the nineteen forties in the United States.

Another factor that has helped the spread of mobile phones in poor countries is its ability to keep in touch people who are separated by great distances. For example, members of one family who are forced to separate when the husband migrates to a big city to find a job. Mobile phones and wireless networking systems are also ideal for people living in remote areas where no fixed communications infrastructure exists, and that change their place of residence from time to time.

Mobile phones have features that make them different from other ICT. They are relatively inexpensive devices, small, portable and have battery with a strong autonomy. There is a second-hand market that allows people in poor countries to buy a cell phone to a relatively low price. Sometimes several people or groups of people have access to a shared mobile phone (Banks, 2008). The second hand market is originated in rich countries, where people tend to change their mobile phone regularly. The terminals that are not used any more in rich countries go to poor countries, where they are sold at a lower price.

Unlike desktop PCs, mobile phones require fewer infrastructures and are easier to maintain. In places where there is no electricity, recharging the service is offered through street kiosks that charge cell phones with ingenious systems such as car batteries or dynamo powered bicycle. In addition, mobile devices are relatively resistant to heat and dust when compared with desktop PCs.

Although mobiles have greatly simplified the provision of services and reduced the cost of infrastructure, most of the growth has been in urban areas. Mobiles are still expensive to be bought and used by the poor. This slow growth is often hidden (rural statistics are not disaggregated from overall national statistics for example) (Shanmugavelan et al., 2009).

\section{2.- Common uses of mobile phones in developing countries}

Chipchase and Tulusen (2006) analyse some of the uses of mobile phones in developing countries. Some of these uses are described next.

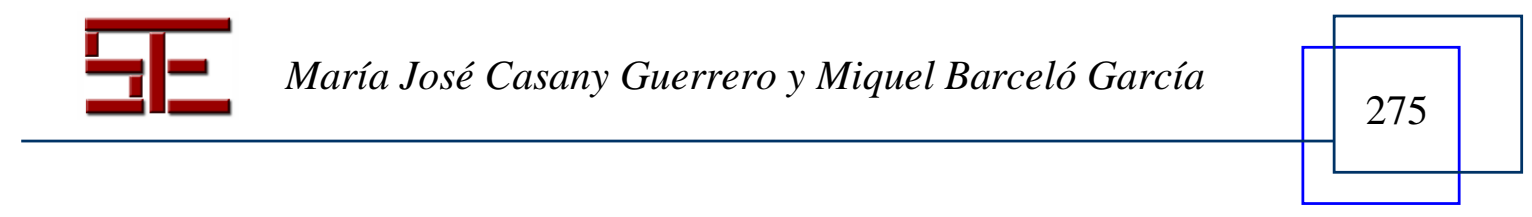




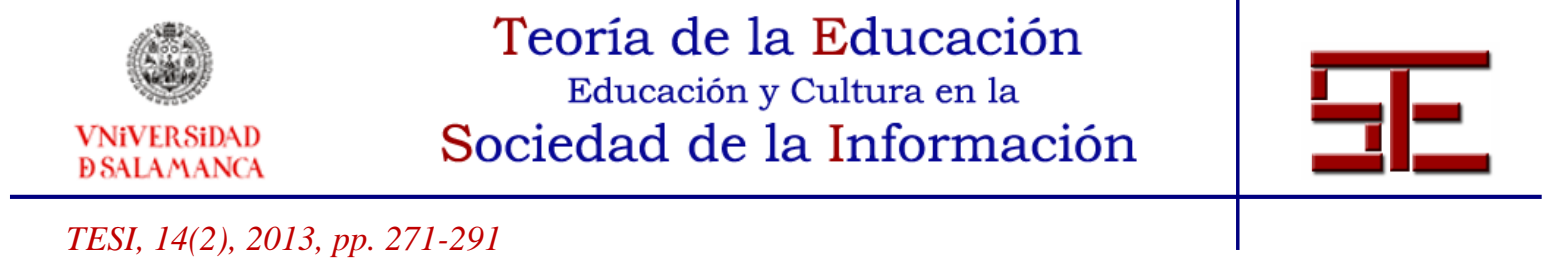

Sente is an informal, save and cheap way to send money to someone using the local kiosk operator. The kiosk operator business is to resell the mobile phones airtime. This system to send money is used in places with limited access to backing infrastructures and is based on necessity.

Lost calls is a tool used to send messages free of charge. For example, when a person arrives to a certain destination types a lost call to a relative. This lost call is used to tell the relative that the other person has arrived at its destination.

In many developing countries there are high levels of illiteracy. Many illiterate people that want to do a phone call only have a piece of a paper with the number written on it. They go to the local kiosk operator in order to do the phone call. Besides, the local kiosk operators usually keep an agenda of the important phone numbers of the village.

The pooling prepay credit system consists of buying shared airtime between people from the same group, for example friends. In Uganda, for example, it is possible to buy airtime slots for a relatively low cost. The airtime is charged in the mobile phone of one of the persons of the group. They can either use the same phone until the airtime is consumed or they can send the remaining airtime to another person via an SMS message. This system has different names depending on the country.

In many developing countries there is a repair culture that has disappeared in most developed countries. In many developing countries they usually repair anything, including mobile phones or their components. This culture is a more sustainable way of managing spare parts that we do not share any more.

The mobile phone recharge service, usually provided by people in the streets, is used to charge different models of mobile phones for a price. This service is important in places where people usually do not have power supply or where the power supply is intermittent. The Village phone initiative provides mobile phone coverage to rural or remote areas. A micro-emprenedeour can ask for a loan to buy a Village Phone Kit, that is composed of a nokia 1100 adapted cell phone, cable to connect the cell phone to an antenna an a battery. The kit costs about $200 \$$ and may provide coverage for $30 \mathrm{~km}$.

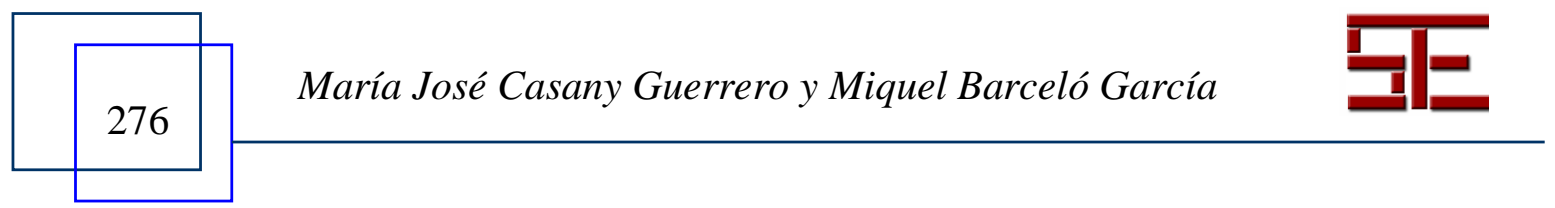




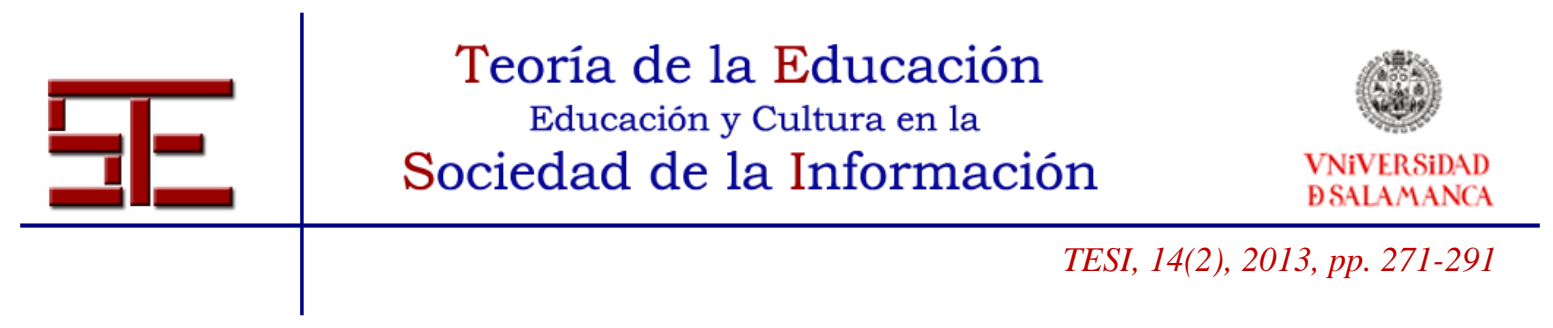

\section{3.- FOSS tools for mobile devices}

There are many Free and Open Source (FOSS) tools and services available for mobile devices. A selection of these tools is presented in this section. The different tools have been organized in the following groups:

- Messaging tools: that includes SMS and MMS related tools as well as voice message applications.

- Data collection applications: that include tools used to collect survey data and send it back to a laptop or server computer.

- Mobile web sites creation tools: are tools to adapt web content to mobile devices.

- Web, e-mail and social networking tools for mobiles.

Messaging tools are tools to send data from mobile devices to laptops/servers or the Internet. SMS related tools used to create SMS-based applications are a very large group of tools. These applications usually collect data from a mobile device and send it back to a laptop/server or the Internet. A couple of examples of these types of tools are:

SMS hubs is a system used to send and receive large amounts of text messages via the mobile phone network, without needing to be connected to the Internet or to any other computer network. A laptop or desktop computer with a number of mobile phones or GSM modems attached is needed. A GSM modem is a small device without a keypad or screen connected to the laptop. It works like a mobile phone, but it is controlled through the computer. Messages are sent and received using software installed on the computer, which transmits them through the attached phone or modem to the available mobile phone network. Because SMS hubs do not need to be connected to the Internet, they are very useful for NGOs working in areas where access to the Internet is not possible or is unreliable.

RapidSMS is an open-mobile project for data collection and communication that allows both quantitative and qualitative data through SMS forms and bulks SMS messaging features. It is designed for "mass-scale" monitoring and data collection. Quantitative data collection is done through the creation of SMS forms that consist of a keyword followed by several questions (fields). For example, "LSTMKT 203015 " could be used to monitor the report on the trading activity in a livestock market with 20 goats, 30 cattle and 15 camels being traded. Data from the forms can be edited through the RapidSMS interface, exported to Excel or displayed with a built-in graphing tool.

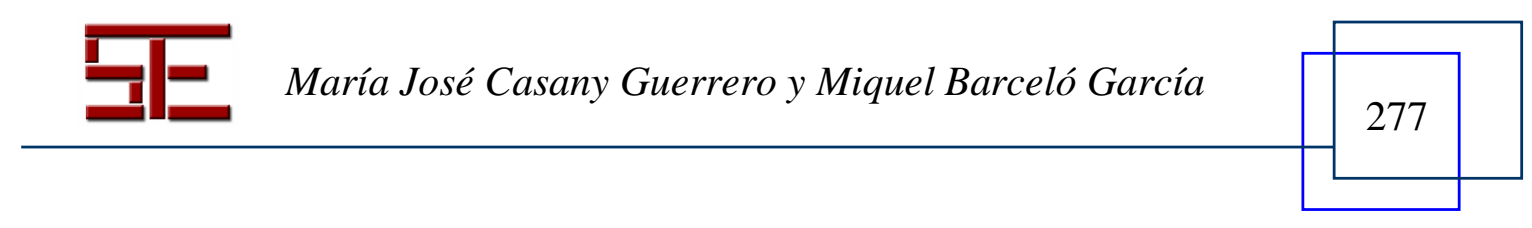




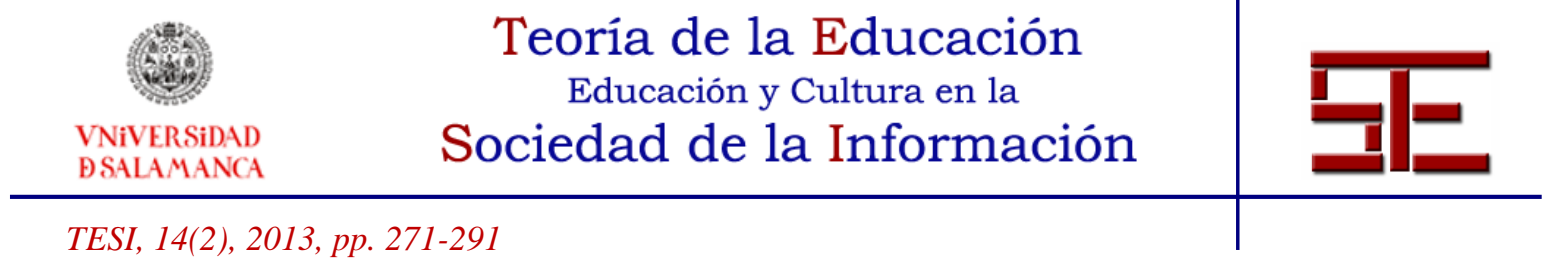

Apart from SMS-based application, there are tools or applications for mobile devices that allows the user to send voice messages or publish multimedia contents to the Internet. For example, the Gizmo open source project is a communications application, which is installed on the mobile phone to send voicemail messages via email. The Shozu application is used to publish multimedia content on the Internet directly from your mobile phone.

Data Collection Applications are applications used to collect data from a mobile phone and send it back to a server/computer. For example, EpiSurveyor is a free Open Source tool, which runs on Personal Digital Assistants (PDAs) and will soon be available for other types of mobile phone. It allows designing a form for a survey on a computer and sending it to the PDA. Then, the user conducts the survey using the PDA and sends the information gathered back to the computer.

Mobile Web Sites Creation Applications are applications used to create a version of a web site adapted to a mobile device, for example, MoviSiteGalore or Nokia Mobile Internet Toolkit.

Web, eMail and Social Networking tools make it possible to access email or social networking site on the mobile phone. Several examples of these tools are: OperaMini is a web browser designed specifically to make the most of viewing web pages on the mobile phone. Facebook mobile is a version of the popular social network for mobile devices. Gmail or Hotmail mobile are versions of the Gmail and Hotmail client for mobile devices.

\section{4.- Disadvantages of mobile technology}

The main disadvantages of this technology are, firstly, the shortage of some of the materials used to make electronic components to manufacture mobile phones (for example coltan). The extraction and exploitation of these materials can and is producing various kinds of conflicts over the control of minerals in the countries where those minerals are extracted (often poor countries).

Secondly, the planned obsolescence of technology is another issue. Although there is a second and third hand market for mobile phones in poor countries, at the end, a lot of junk remains and has to be processed.

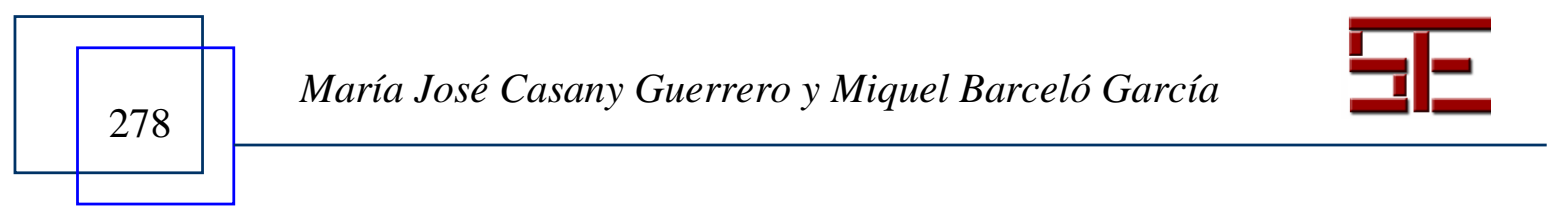




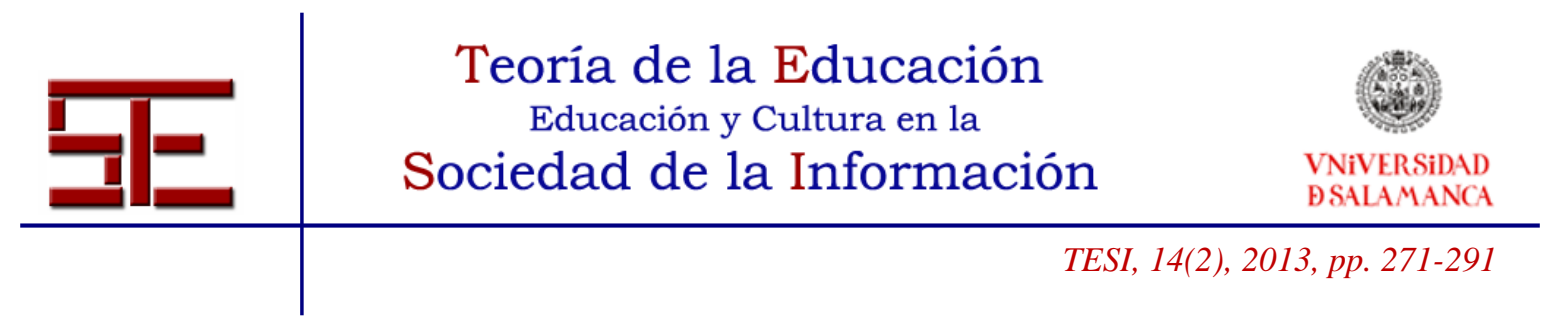

Finally, although many mobile phone manufacturers have incorporated regulations to ensure workers' rights and environmental measures that affect the products they manufacture, these measures often do not apply to subsidiary companies. This is the case of the company called Foxconn located in Taiwan, leading global manufacturer of electronic components; this company has appeared several times in the media due to controversy over how the company treats employees.

\section{3.- M-LEARNING FOR DEVELOPMENT}

\section{1.- Introduction}

The rapid growth of mobile technologies and services in developing countries make academics and other professionals think that mobile technology has a great potential to help improving education in developing countries and achieving universal primary education (one of the Millennium Goals proposed by the United Nations). Through the Institute for Information Technologies in Education (IITE), UNESCO has made a recent and important strategic commitment to mobile learning. UNESCO identifies m-learning as a key enabler in furthering the Millennium Goal of achieving universal primary education (GSMA, 2011). Mobile technology may also be used to fight against the digital divide and for sustainable development.

The application of mobile technology to support learning is called mobile learning or $\mathrm{m}$ learning. M-learning may be defined as the learning that takes places in different places or that takes advantages of portable technologies. During his learning process, the learner interacts with different types of technology (mobile or fixed) (Sharples; ArnedilloSánchez; Milrad; Vavoula, 2009).

Since mobile technology is extended in many developing countries it may be used to improve development (this is usually called m-learning4D). This section analyses the related work in this area as well as the challenges that faces m-learning in developing countries.

\section{2.- M-Learning for Development: related work}

This section presents a review of some m-learning projects for development in developing countries. The bibliography has been organized in the following groups:

- Proposals of using m-learning to support the learning process.

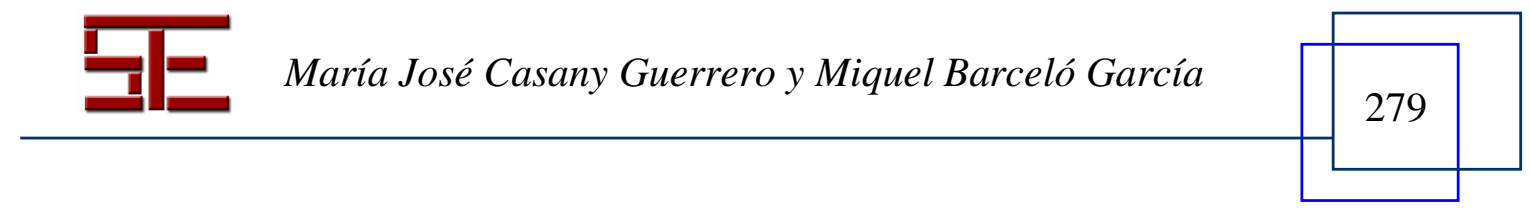




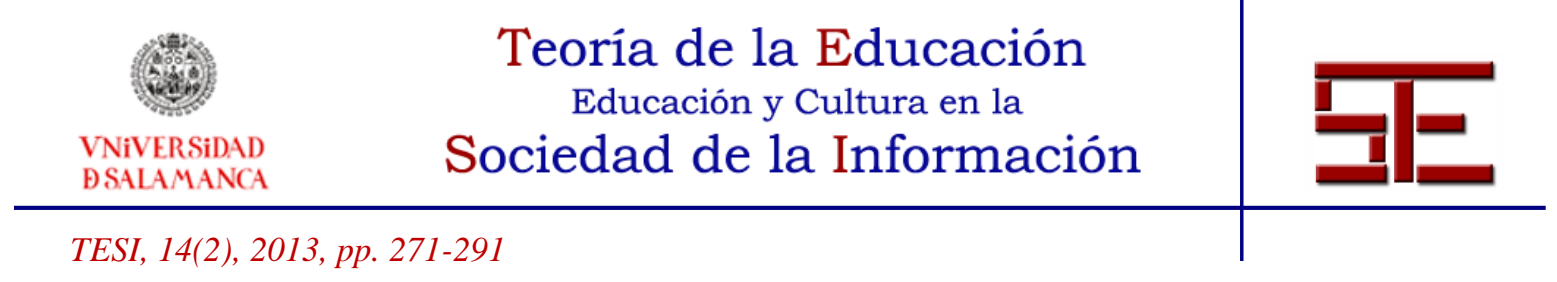

- Proposals to analyze how m-learning can fight the digital divide.

- Proposals to study broadcast sustainable development values using mobile devices.

- Proposals promoting mobile technologies and services development at academic institutions.

- Proposals to fight against illiteracy using mobile devices.

\subsubsection{Proposals of using m-learning to support the learning process}

Among the studies that use m-learning to support the learning process, the work of Traxler and Leach (2006) and Chandran (2010) are very relevant. Traxler and Leach (2006) present two projects: the DEEP and the SEMA project. The Digital Education Enhancement Project (DEEP - www.open.ac.uk/deep) carried out an initial study into the potential of ICT for teacher education in developing nations, working with teachers and institutions in Egypt and South Africa.

The overarching research questions for DEEP were:

1. How does ICT transform the pedagogic knowledge and practice of teachers and the communities in which they live and work?

2. What is the impact of ICT-enhanced strategies on pupil achievement and motivation?

The SEMA project was started in Kenya in 2003 to support school based teacher development. The project used SMS messages broadcasting for several purposes such as: delivering study guide material, content such as hints, tips or summaries, reminders or urgent messages about errata or cancellations.

Both projects analyse the impact of mobile technologies in the pedagogy of teachers. Both projects use different hardware: the DEEP project uses PDAS and laptops while the SEMA project uses GSM mobile phones. The number of teachers involved is also very different. While the DEEP project involved about 50 teachers, the SEMA project involved about 100000 teachers. Both projects conclude that the long term sustainability of the project is one of the challenges of m-learning in Africa. Finally, Chandran (2010), from the Vinayaka Missions Distance University, studies how mobile technology may affect sustainable distance education in a multicultural context. Some students of History,

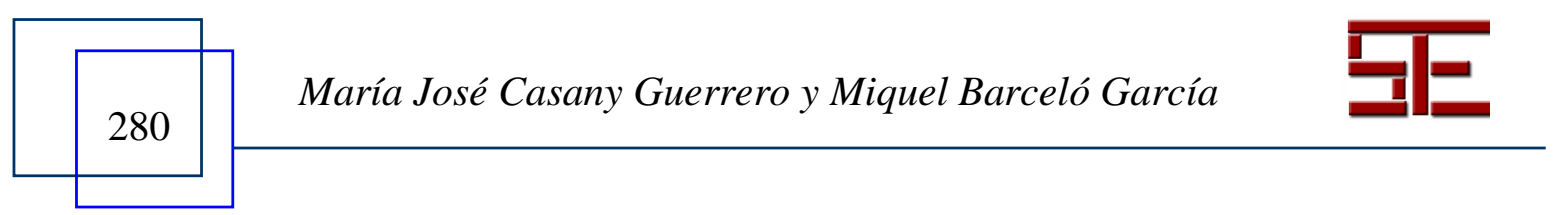




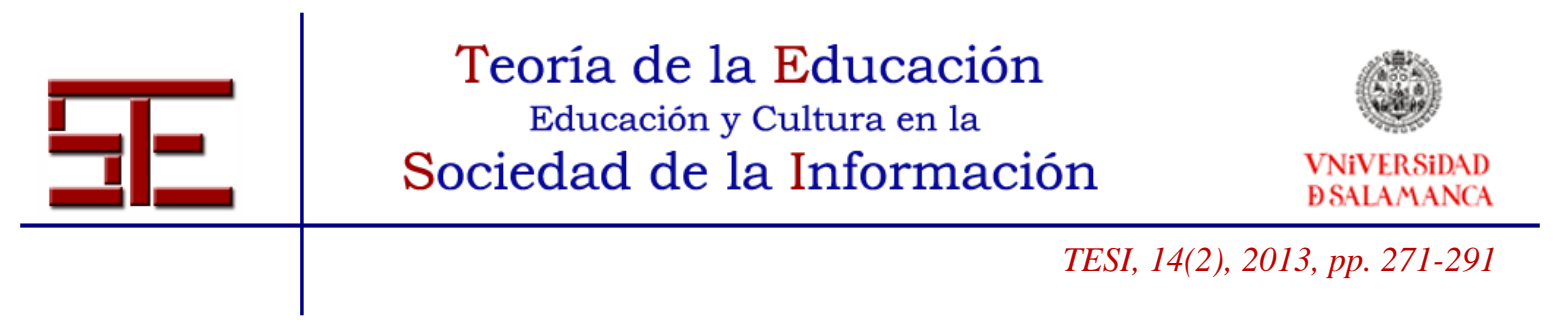

Economical and Political sciences where given the opportunity to participate in an experiment conducted in the subject of public politics. The contents of the subject where organized in lessons and each student participating in the pilot had to prepare a list of questions and answers for a specific lesson. Besides, each student received the list of lessons prepared by the other students. Mobile phones where used to send the lists of questions and answers as SMS messages and attached word files. Discussions forums where used among students to discuss the different lessons. The conclusions of this study are that students that participated in the experiment got better grades than the rest. In this study, mobile devices are used to enhance collaboration and interaction.

\subsubsection{Proposals to analyze how m-learning can fight the digital divide}

Among the studies to fight against the digital divide using mobile devices, two of them (Litchfield; Dyson; Lawrence; Zmijewska, 2007) and (Laouris \& Laouri, 2008) suggest that it is important to find strategies to implement low-cost m-learning projects. Laouris and Laouri (2008) propose some work directions in order to use m-learning to fight against the digital divide. They consider that some of the initial expectations of $\mathrm{m}$ learning in developing countries have not been achieved because the projects are not yet consolidated. There may be needed a larger period of time to analyse the results of these projects.

According to the previous authors, two strategies to fight against the digital divide are needed:

- International community must promote initiatives to take low-cost tech to poor countries.

- Poor countries must understand that tech is related to development. They must start to implement low-cost viable and mid term projects.

From the learner point of view Brown, (2004) proposes a model for m-learning in Africa. He states that m-learning may help learners from third world rural or remote areas who have access to a mobile phone. The University of Pretoria (South Africa) started an mlearning pilot project in 2002. Three existing programmes of the Faculty of Education adopted the m-learning pilot project. This pilot project was launched based on the fact that $99 \%$ of the students had mobile phones and that most of them lived in rural areas with no fixed ICT infrastructure. The pilot project used bulk SMS to provide students with basic administrative support. The SMS focussed on reminders of important dates for

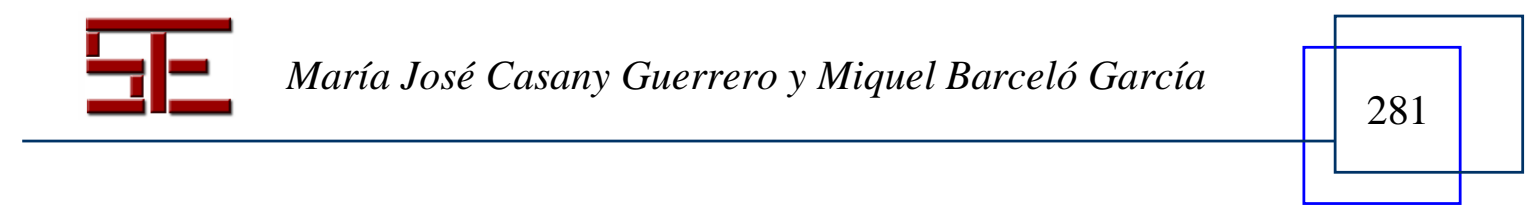




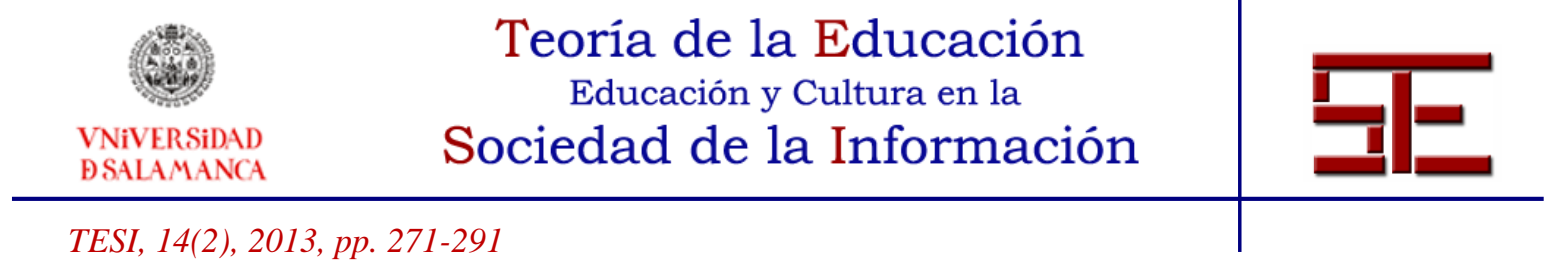

activities like contact classes or examination registration as well as notification of study material distribution.

The project was successful because learners responded in mass and almost immediately on information provided in SMS-messages. Instead of using SMS bulks, using print and postal service to distribute the necessary information to students, would have been more than 20 times the cost of the bulk SMS. While SMSs provided just-in-time information, the posted information would have taken between 3 and 18 days to reach the learners. Some conclusions of the project were that:

- M-learning is a supportive mode of education.

- M-learning provides flexibilities for various learning and lifestyles.

- The most appropriate mobile device for learners in Africa is the mobile phone.

The project One Laptop Per Child (OLPC) is another initiative to fight against the digital divide between rich and poor countries. The main goal of this project is to give the poorest children of the world one low cost computer to help them take advantages of ICTs. With this idea in mind, a new small durable laptop was created. This laptop has unique innovative features such as a unique design, resistance to adverse weather conditions, high autonomous battery, open source software and new minimalist interface. Some authors (Camfield; Kobulsky; Paris; Vonortas, 2007) and (Warschauer \& Ames, 2010) believe that the main drawback of the OLPC project is that it is solely a technological solution without an educational approach. Since it is not an educational project there are not pilots that may be used as reference to evaluate the use of this laptop to fight the digital divide. Another problem of the OLPC laptop is its distribution model. In order to take advantage of scale economies and be able to sell the laptop for a low price, the countries that are interested in buying the laptop must buy large orders. This is a serious drawback because many countries are reticent to invest large amounts of money in this laptop especially when other companies offer them similar laptops (such as Asus Educational PC) for a low price.

Ford and Botha (2007) presented the MobiED project that consisted in the creation of an audio Wikipedia. The users may send term queries to the Wikipedia server using SMS messages from their mobile phones. The server answers the query with a phone call where a synthesizer reads the answers. If the term is not found, the user may contribute by dictating its definition. The pilot consisted in two stages: in the first one a simplified version of the system was tested in a private school of Pretoria (South Africa) and in a

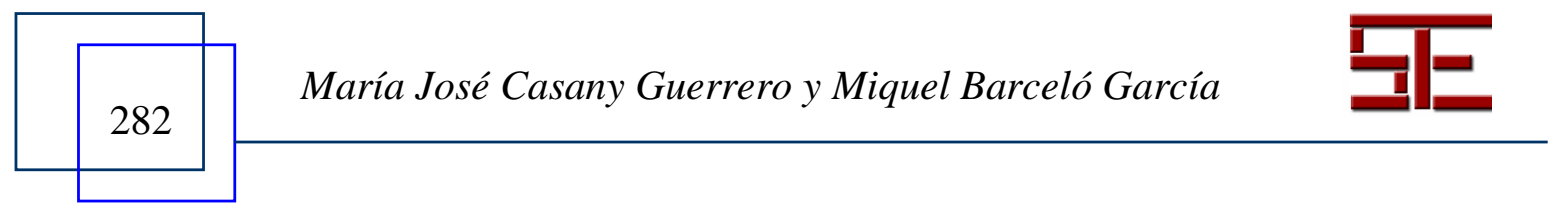




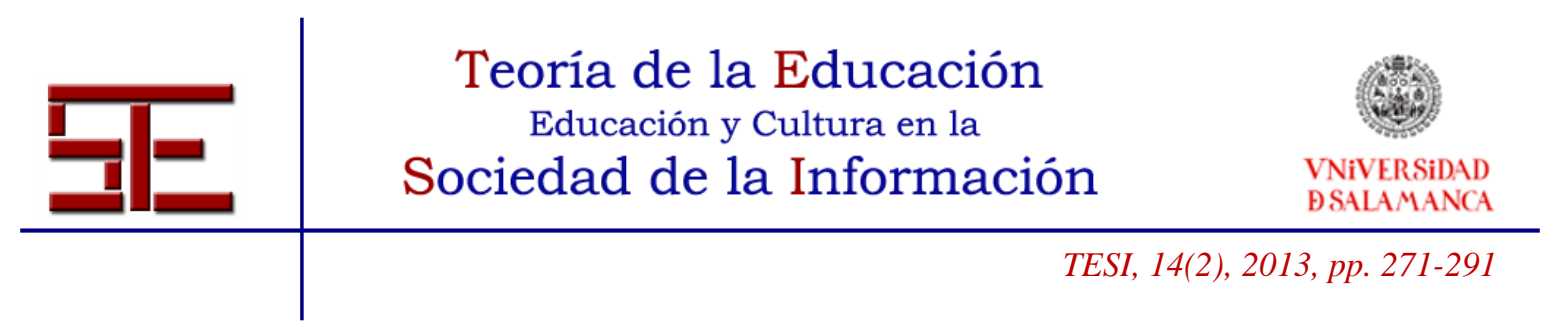

second stage it was tested in public school of a rural area. Due to the good results of the study, authors explore the possibility of using m-learning as a de-facto platform in Africa.

\subsubsection{Proposals to study broadcast sustainable development values using mobile devices}

Other projects (Chen \& Hsu, 2007), (Froehlich et al., 2009) study how to broadcast sustainable development values using mobile technology as support systems. Chen and Hsu (2007) designed an m-learning module for sustainability in education. A mobile device carrying self-guiding trip instructions was given to 14-year-old students to conduct a field trip without the company of the teacher. The goal was to visit 5 viewpoints showing various environmental problems in Taipei (Taiwan), caused by bad usage of natural resources. The students were asked to collect field data such as pictures or interview local residents to evaluate 3 scenarios regarding the future development of the affected zone. The results of this study showed that both teachers and students agreed that the m-learning application had helped them understand local environmental issues as well as concepts of sustainable development. (Froehlich et al. 2009) presents the project UbiGreen, an initiative to analyse the transport habits in two North American cities. The study starts posing two tests (one online and the other mobile) to the people that participates in the study. The people participating in the study are interested in changing their habits to be more ecologic. Another goal of the study is to know which is the main motivation to drive to work instead of taking public transport. The results of these polls are used to design a mobile application called UbiGreen Transportation Display that semi-automatically gets information about transportation habits of the person carrying the mobile phone. If the system cannot infer the mean of transportation it asks the users. The main goal of this application is motivate people to use more ecological means of transportation.

\subsubsection{Proposals promoting mobile technologies and services development at academic} institutions

(Mekuria, 2008) and (Mekuria \& Rai, 2008) described a master in mobile computing developed at the Makerere University (Uganda) that will help develop more advanced mobile services adapted to the socio-economic situation of developing countries. This master programmes provide students with knowledge to develop software applications and services for mobile devices as well as to promote sustainable development because students that finish the programme go back to their home village with a mobile service to be tested by the people of the village. Students learn important knowledge to develop mobile services. Another project to promote studies to create mobile services is Mobitel

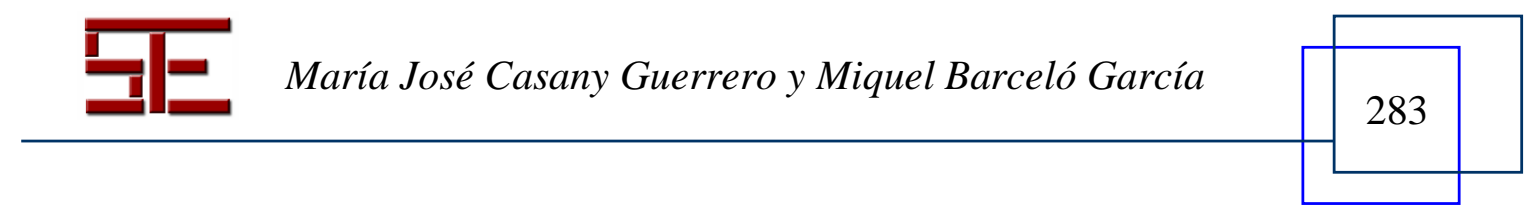




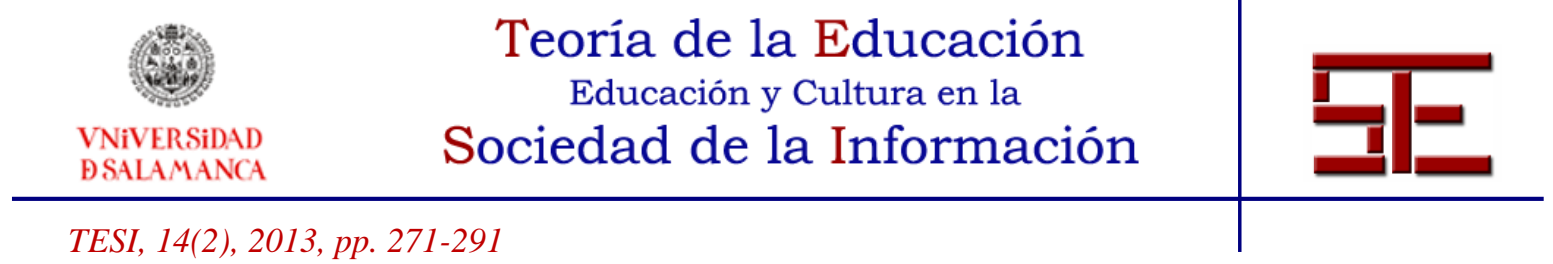

(GSMA, 2010). It is the first national mobile service provider in SriLanka. Mobitel first trialled a m-learning platform facilitating the Faculty of Graduate Studies, at the University of Colombo to deliver its diploma in marketing via m-learning. Following the success of the trial the m-learning platform was extended to more faculties to offers several other programs.

\subsubsection{Proposals to fight against illiteracy using mobile devices}

Finally, other projects are centred in helping improving literacy (mobilink) or skills in specific subjects such as maths (Momaths) or English (Janala) (GSMA, 2010). Kim, Miranda and Olaciregui (2008) study the possibility of introducing m-learning activities in groups of very poor children of South America. These children usually live in remote areas and have an itinerant life due to their parents work. They do not have access to primary education and reading materials. Their parents are also illiterate and have no possibilities to help their children. The main goal of this study is to analyse the social phenomenon of introducing m-learning activities in this context to help children learn to read. The experiment conducted consisted in giving these children mobile phones loaded with educational activities for children between 3 and 13 years. The activities included activities to learn the alphabet as well as other reading activities. Some of the conclusions of the study are that children learned very quickly (in minutes) how to use the mobile phone. Older children that could read were able to tell the others the stories at the same speed as if they were reading in a book. These activities were amusing for children and provided them with access to some reading materials.

\section{3.- Challenges of m-learning projects}

Some of the challenges that faces m-learning initiatives have been analysed previously (Zuga; Slaidins; Kapenieks; Strazds, 2006), (Litchfield et al. 2007). Some of them are summarized below.

- Partial opposition to change the traditional practices of educational institutions.

- No motivation to change technology because many times it involves new requirements and change the way of doing things.

- Need to spend much time in customizing and adapting materials and content to different types of devices or platforms.

- The cost of introducing m-learning is still high because hardware and Internet connections are still expensive. It is necessary to find low-cost solutions to maintain product sustainability.

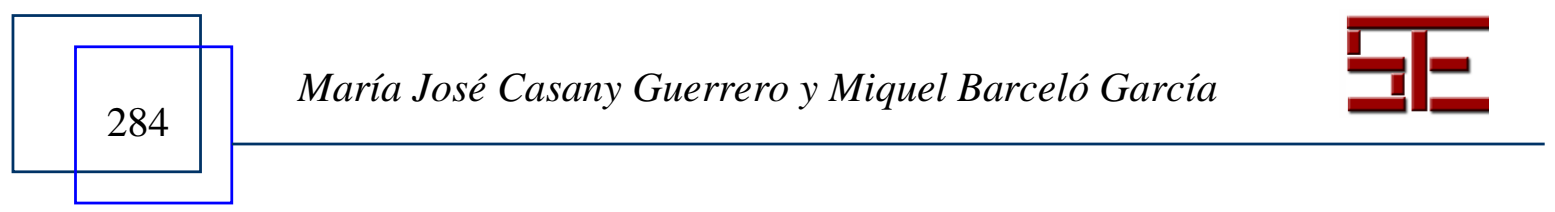




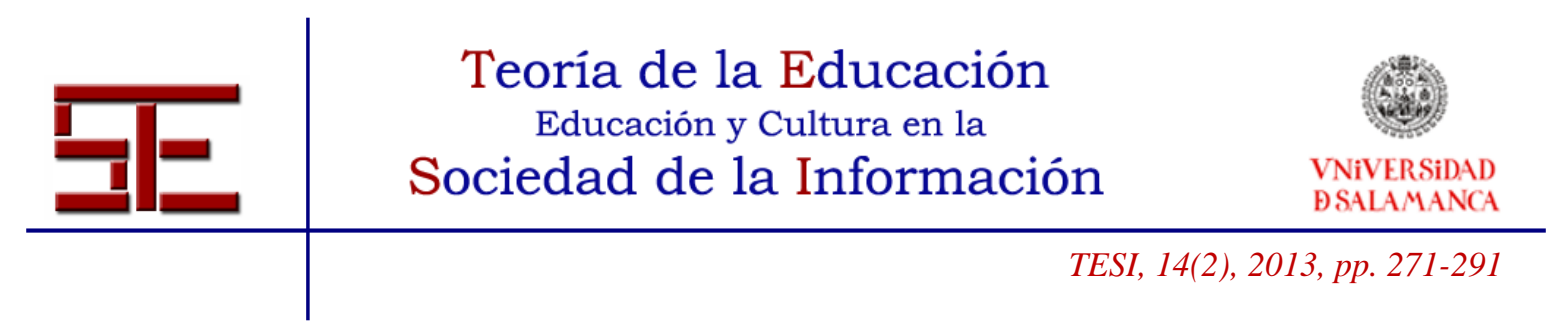

- Mobile phone companies show little interest in sharing knowledge and applications because it does not have a direct benefit.

- Many of the m-learning projects are pilots or small-scale projects. It is necessary to define projects with more impact

- It is necessary to consider that there are different socio-cultural realities in order to create content and services for developing countries.

\section{4.- PROPOSAL TO DEFINE MORE SUSTAINABLE M-LEARNING PROJECTS}

According to Heeks (2009) in the near future the application of ICT for development is focused on 1) research on mobile devices, 2) evaluation of the potential of web 2.0 and FOSS for poor communities, 3) study the integration of different types of ICTs, 4) research in order to create more resources for poor local communities. We have adapted these ideas to identify several key aspects that may contribute to create more sustainable m-learning projects.

To overcome some of the challenges that face many m-learning projects the integration of m-learning tools with other ICTs (such e-learning platforms) could be useful. This extension could extend the scope of the m-learning tool because many educational institutions already use an e-learning platform. According to (GSMA, 2011) mobile learning applications are most powerful when they are linked to an institutions LMS compatible with mobile devices.

Another idea to have more successful m-learning projects is achieve local participation and collaboration. This idea is borrowed from Web 2.0 and FOSS practices. One of the characteristics of the social revolution of Web 2.0 is that Internet users may no longer be passive information consumers; they may become information or content creators. This change is affecting people all over the world, including developing countries. More active users that participate in the creation of information and knowledge arise. Moreover, according to Thomas (2010), Web 2.0 and FOSS practices have several elements in common, because collaboration and sharing of information are also characteristics of the FOSS movement. Nowadays, there are many open source tools to engage collaboration and participation, available for a very low cost. Theses tools are available so that the poor can spread their message.

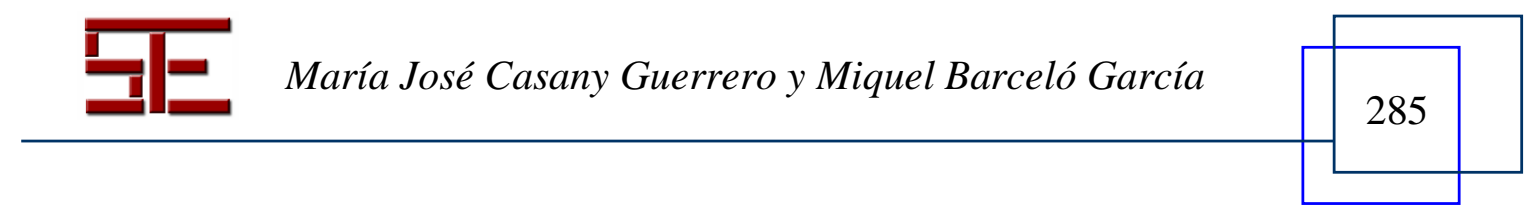




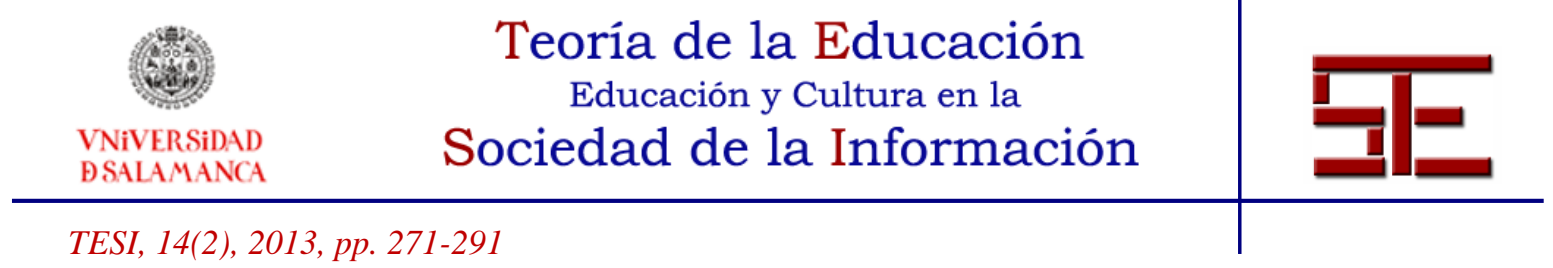

"Technological innovation is taking place at a breath-taking pace. Simple, open source internet-based applications and services designed to enhance on-line collaboration are now available to the wider public at little or no cost at all. These new online technologies known as Web 2.0 applications - sometimes called 'social media' - enable people to collaborate to create share and publish information". ${ }^{1}$

Finally, more resources and contents are needed for mobile devices. These contents must be appropriate for local communities needs. Programs to help the poor learn how to use ICT are also needed. The information needs of rural communities may differ depending on the socio-economic conditions of their residents. However, studies have shown that the information needs of rural dwellers centre around their basic day to day needs (Ahmed, 2009), (Dutta, 2009).

In summary, the previous points may help overcome some of the challenges of m-learning projects such as the adaptation of contents and services to mobile devices and the sustainability of m-learning projects once the initial stage finishes.

To improve the implementation of m-learning projects, authors propose a series of guidelines that are described below:

1. Engage local motivation and participation: It is important that the community shows its interest and motivation for the project. Otherwise the project may not be used. It is also important that the local gatekeepers (such as community leaders, local politicians, schoolteachers, etc.) participate in the project. A committee for implementation of the project should be formed involving representatives from all community groups. The committees have to be accountable, responsible for accumulating human, physical and financial resources, plan and manage diverse activities, mobilize and network with different organizations as well as monitor and evaluate tasks assigned to them.

2. Promote education in ICT and development of local capacities: The community members will need some sort of training exposure to ICT to further their understanding of the project. They need basic training on how to use mobile phones, the software and on handling information and services provided by these

1 http://www.web2fordev.net/component/content/article/1-latest-news/156-web2lo-istt-zam (accessed April 2012).

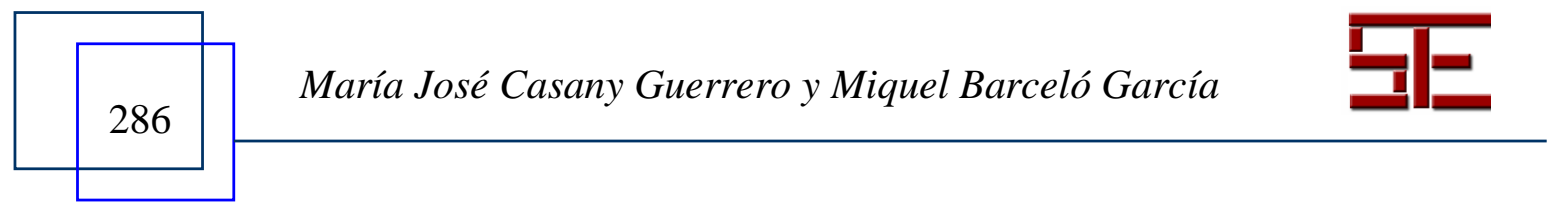




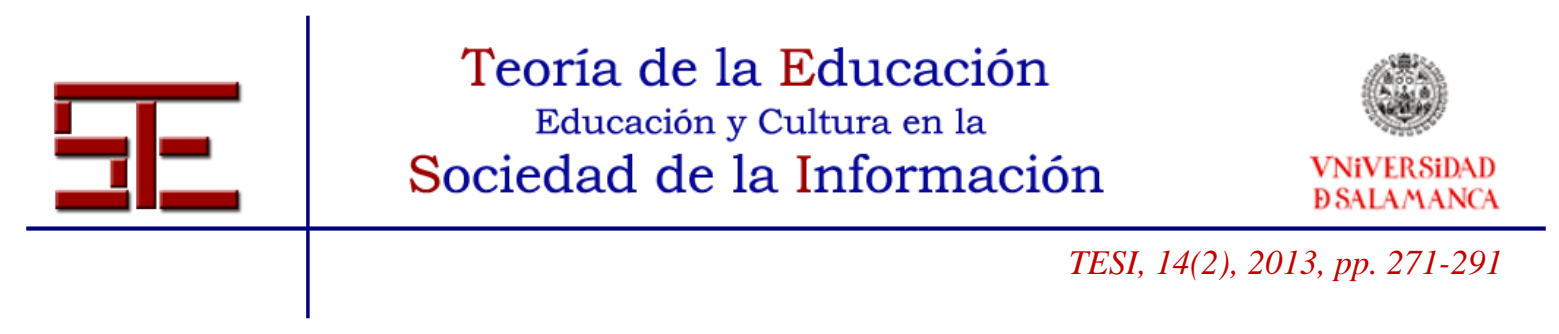

devices. Some times the role of the "info-mediator" may be used to help people that cannot use technology.

3. Collaboration with external participants: This may be interesting especially at the beginning of the project where external funding is needed to start the project. It may be also possible that technical experts from abroad are needed to start the project.

4. Create a plan to guarantee financial viability: a plan to fund the project once the initial stage is finished is needed in order to guarantee the project's sustainability.

5. Use mobile technology as basic platform: the main technological component must be mobile phones, because it is the only ICT that most of the people in developing countries have access to. However, this mobile technology must not be linked to a specific platform in order to avoid paying licences.

6. Use FOSS software: Usually people in developing countries do not pay attention to this issue. Van Reijswoud (2008) analyse the use of FOSS in developing countries. The results of this study shows that many people in developing countries do not care about the type of software they use (proprietary or FOSS). According to BSA (2009) most of the countries with a pirate software rate exceeding $85 \%$ are developing countries. The norm seems to be using private software although it is obtained illegally. It seems that a FOSS movement is missing in those countries. Local Governments do not pay attention on the subject of FOSS. To promote FOSS, advantages of using this type of software should be explained as well as the multiple FOSS tools available on the Internet. Furthermore, the development of m-learning projects should be based on participation and collaboration.

7. Localize the software: The software used must be able to adapt to the language of local people. Otherwise, it may not be used at all.

8. Update the software locally: the ability to be able to update and maintain the system with local capacity.

9. Scale the software locally: once the pilot project has finished the project must have a plan to maintain its sustainability. It may have to be enlarged. This must be done locally.

10. Local ownership. Some approaches to the implementation of m-learning have included sponsorship from device manufacturers which has enabled organizations to provide whole cohorts of learners with devices. Although this is useful, it raises issues of ownership and sustainability. Another approach to provide devices to learners is assisting them to buy an inexpensive device (UNESCO, 2010).

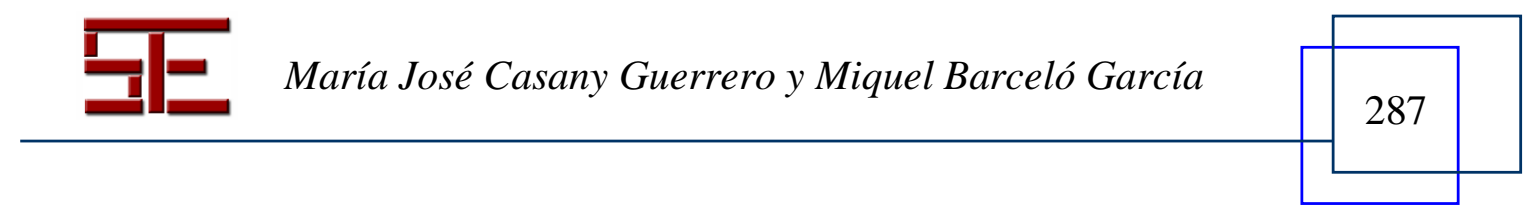




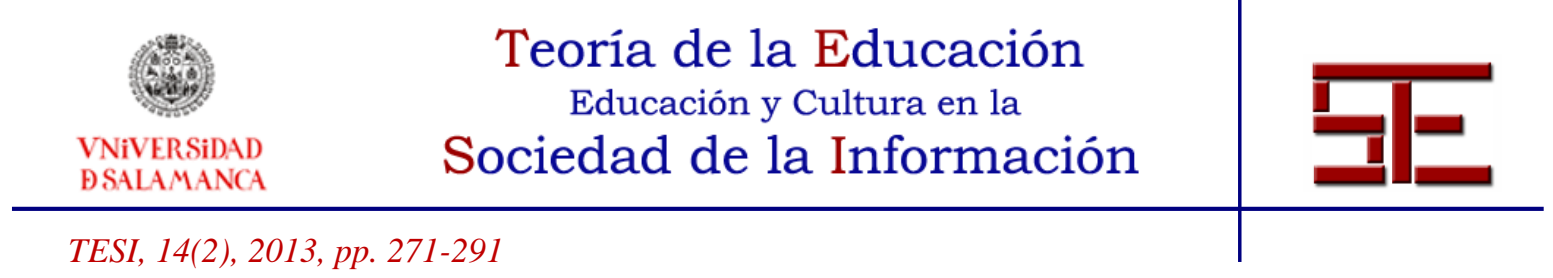

\section{5.- CONCLUSIONS}

In the next years mobile phones are going to be nearly universally adopted. We could say that the computer of the future is a mobile phone. Mobile phones are starting to be a good asset for development, education and fighting against the digital divide. This paper presents some insights on how mobile phones are being used in developing countries for development.

The expansion of mobile telephony in developing countries has made possible the creation of new mobile services related to health, agriculture or education. Regarding mobile services for education, this paper presents a tentative classification of current $\mathrm{m}$ learning projects for development.

In spite of the increasing number of mobile services available for mobile phones, $\mathrm{m}$ learning services face several challenges regarding its long-term sustainability and impact. The high ICT illiteracy levels are limitations to the success of m-learning projects. This proposal aims to help define more sustainable m-learning projects, using some of the practices borrowed from Web 2.0 and FOSS methodologies.

\section{6.- REFERENCES}

Ahmed, S. M. Z. (2009). The boat library of Bangprok community in Thailand: an evaluation of its performance and impact. New Library World, 110, $\mathrm{n}^{\mathrm{o}} 11 / 12,498-511$.

Banks, K. (2008, July 29). Mobile Phones and the Digital Divide. In PCWorld Business Center. Extracted on April, 15, 2012 from:

http://www.pcworld.com/businesscenter/article/149075/mobile_phones_and_the_digital _divide.html.

Brown, T. H. (2005). Towards a model for m-learning in Africa. International Journal on E-Learning, 4 (3), 299.

BSA (2009). Seventh Annual BSA/IDS Global Software 09 Piracy Study. Business Software Alliance.

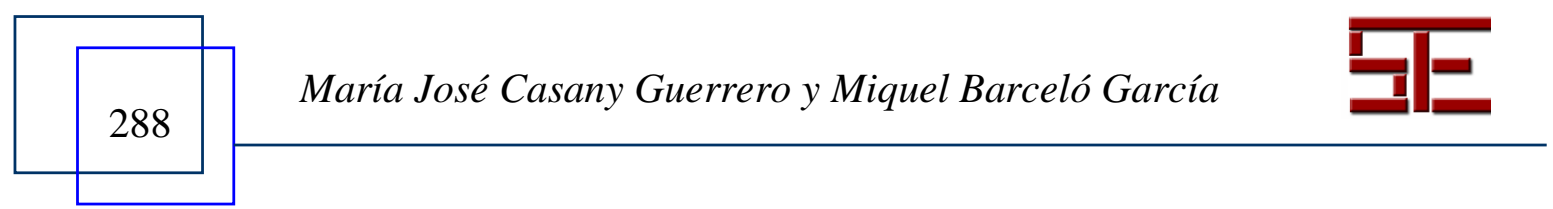




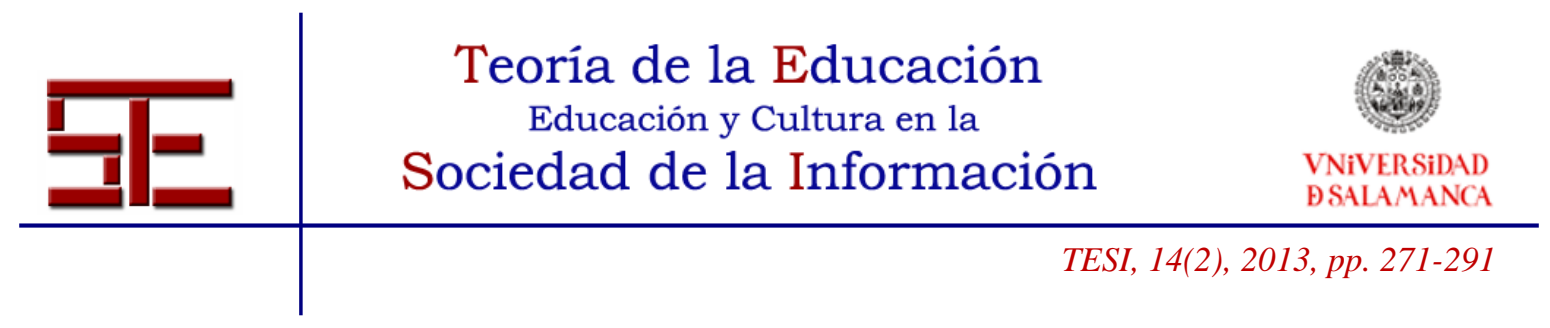

Camfield, J., Kobulsky, A., Paris, J., \& Vonortas, N. (2007). A Report Card for One Laptop Per Child. Closing the Digital Divide via ICTs and Education: Successes and Failures. IAFF 229: Multidisciplinary Seminar in Science Technology and Global Affairs, 6.

Chandran, S. (2010). Sustainable Distance Education Through Mobile Learning: A Case Study in Multicultural Context. OIDA International Journal of Sustainable Development, $2(3), 35-40$.

Chen, C. \& Hsu, T. (2007). Learning Sustainable Development With Mobile Devices. Proceedings of Geographical Views on Education for Sustainable Development. Lucerna, Switzeland.

Chipchase, J. \& Tulusan, I. (2006). Shared Phone Practices: Exploratory Field Research from Uganda and Beyond. Nokia Research Center. Extracted on April, 15, 2012 from: http://janchipchase.com/content/presentations-and-downloads/.

Dutta, R. (2009). Information needs and information seeking behaviour in developing countries. In International Information \& Library Review, 41, nº 1, 44-51.

Froehlich, J., Dillahunt, T., Klasnja, P., Mankoff, J., Consolvo, S., Harrison, B., \& Landay, J. A. (2009). UbiGreen: investigating a mobile tool for tracking and supporting green transportation habits. Human-Computer Interaction Institute (pp. 1043-1052).

Ford, M. \& Botha, A. (2007). MobilED-an accessible mobile learning platform for Africa. IST-Africa Conference Proceedings. Presented at the IIMC International Information Management Coorporation, Paul Cunningham and Miriam Cunningham (Eds.).

GSMA (2010). mLearning: A Platform for Educational Opportunities at the Base of the Pyramid. GSMA Development Fund.

- (2011). Mobile Education Landscape Report. GSMA Development Fund.

Heeks, R. (2009). The ICT4D 2.0 Manifesto: Where Next for ICTs and International Development? University of Manchester, Institute for Development Policy and Management.

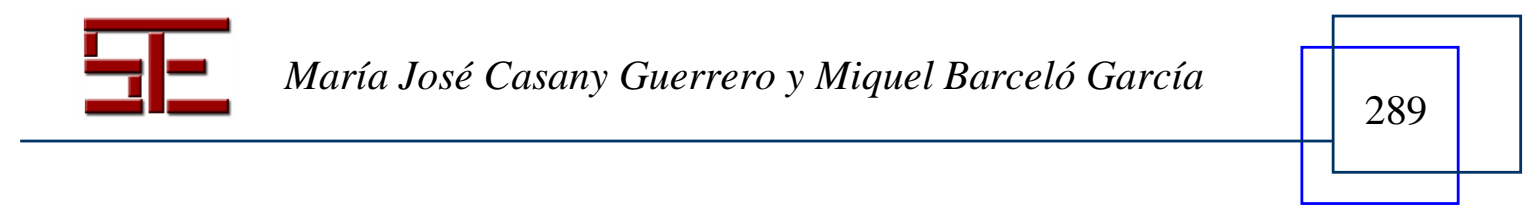




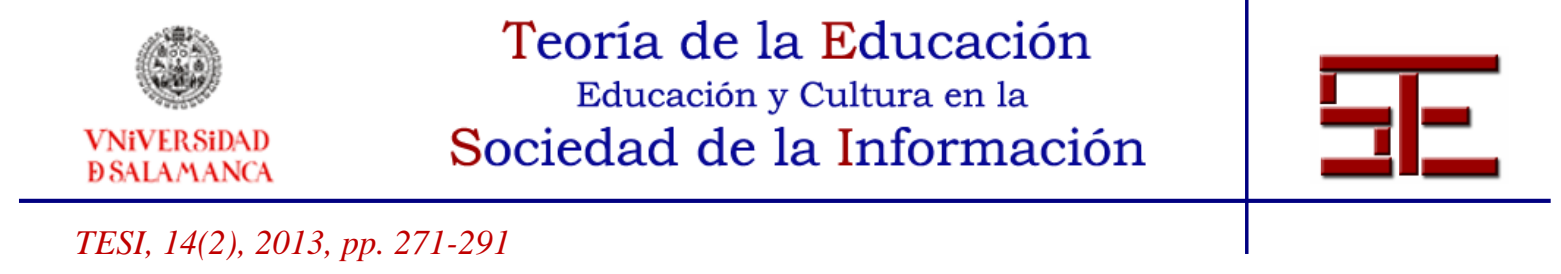

ITU (2010). The World in 2010: ICT Facts and Figures. International Telecommunication Union (ITU), Extracted on April, 15, 2012 from: http://www.itu.int/ITU-D/ict/material/FactsFigures2010.pdf.

Kim, P., Miranda, T. \& Olaciregui, C. (2008). Pocket School: Exploring mobile technology as a sustainable literacy education option for underserved indigenous children in Latin America. En International Journal of Education Development, 28 , 435-445.

Laouris, Y. \& Laouri, R. (2008). Can Information and Mobile Technologies Serve to Close the Economic, Educational, Digital, and Social gaps and Accelerate Development? World Futures, 64 (4), 254-275.

Litchfield, A., Dyson, L. E., Lawrence, E., \& Zmijewska, A. (2007). Directions for m-learning research to enhance active learning (pp. 587-596).

Mekuria, F. (2008). Using Mobile Technology and Services for Sustainable Development in Africa. Strengthening the Role of ICT in Development, 290.

Mekuria, F., \& Rai, I. (2008). Issues in Next Generation Wireless Network Technologies \& Services for Developing Regions. Proc. of Mobicom-08, WiNS-DR.

Peña-López, I. (2008, December, 1). UOC Tech Talks. Jessica Colaço: Mobile technology and social change. InICTlogy, 73. Extracted on April, 152012 from: http://ictlogy.net/review/?p=1445.

Shanmugavelan, M., Warnock, K., \& De Sarkar, D. (2009). Completing the revolution: The challenge of rural telephony in Africa. Communication for Development Programme, Panos Institute.

Sharples, M. (2006). Big issues in mobile learning. Report of a workshop by the Kaleidoscope Network of Excellence Mobile Learning Initiative. Nottingham.

Sharples, M., Arnedillo-Sánchez, I., Milrad, M., \& Vavoula, G. (2009). Mobile Learning. Technology-Enhanced Learning, 233-249.

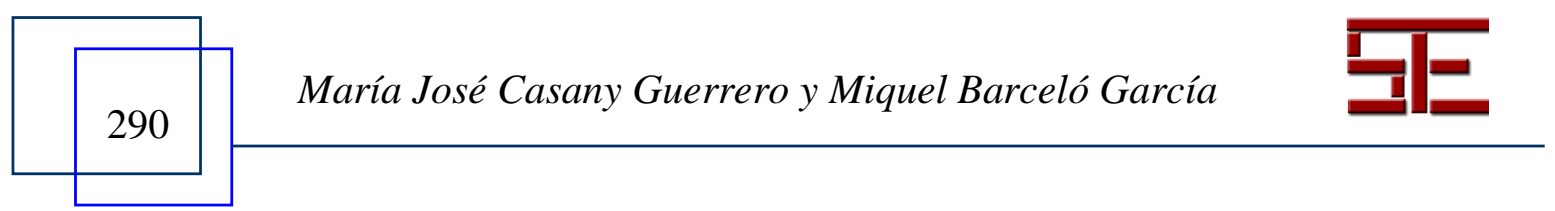




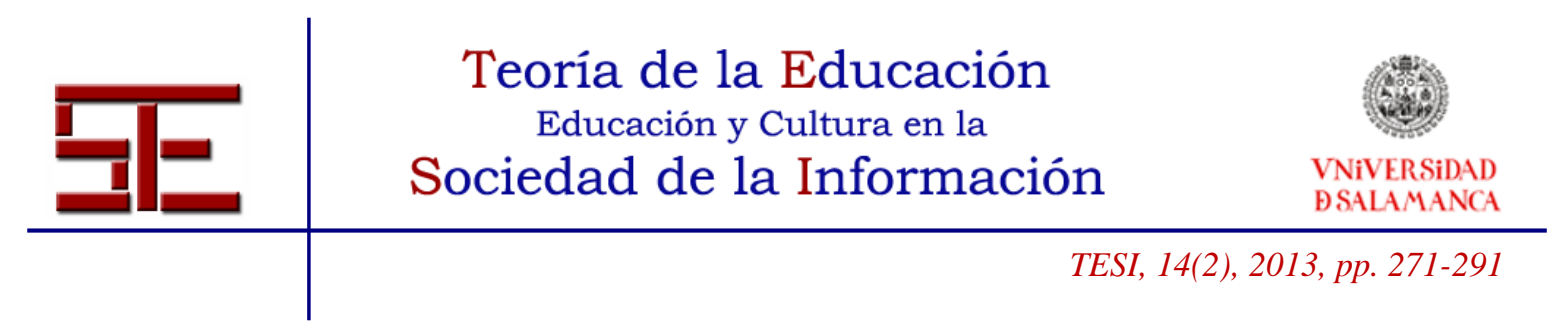

Thomas, B. K. (2010). Participation in the Knowledge Society: the Free and Open Source Software (FOSS) movement compared with participatory development. Development in Practice, 20 (2), 270-276.

Traxler, J., \& Leach, J. (2006). Innovative and sustainable mobile learning in Africa (pp. 98-102).

UNESCO. (2010). Mobile Learning for Quality Education and Social Inclusion.

Van Reijswoud, V. (2008). Free and open source software for development: exploring expectations, achievements and the future (vol. 5). Polimetrica sas.

Warschauer, M. \& Ames, M. (2010). Can One Laptop Per Child Save the World's Poor?. En Journal of International Affairs, 64, $\mathrm{n}^{\circ} .1$.

Zuga, B., Slaidins, I., Kapenieks, A., \& Strazds, A. (2006). M-learning and mobile knowledge management: similarities and differences. International Journal of Computing \& Information Sciences, 4 (2), 58-62.

Para citar el presente artículo puede utilizar la siguiente referencia:

Casany Guerrero, M. J. y Barceló García, M. (2013). Como definir proyectos de mlearning más sostenibles. Revista Teoría de la Educación: Educación y Cultura en la Sociedad de la Información. 14(2), 271-291 [Fecha de consulta: dd/mm/aaaa]. http://campus.usal.es/ revistas_trabajo/index.php/revistatesi/article/view/10224/10632

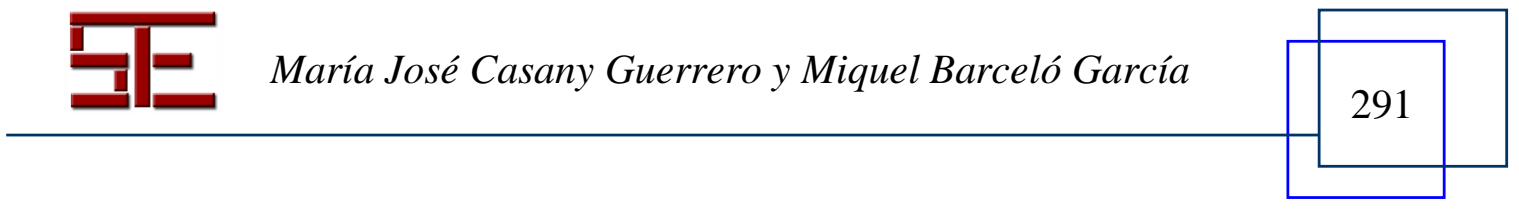

